\title{
The Performance of Equalization Model of Water Allocation Inter Irrigation Areas in River System
}

\author{
Anang M. Farriansyah ${ }^{1}$, Pitojo Tri Juwono ${ }^{2}$, Ery Suhartanto $^{2}$, Very Dermawan ${ }^{2}$, and Rahimatus S. Z. Alyaminy ${ }^{3}$ \\ ${ }^{1}$ Civil Engineering- Doctoral Program, University of Brawijaya, Malang, Indonesia \\ ${ }^{2}$ Water Resources Engineering, University of Brawijaya, Malang, Indonesia \\ ${ }^{3}$ Youth Professional Engineer, Mataram, Indonesia
}

\begin{abstract}
In Indonesia, water is public goods so it is necessary to control water allocation. Inequity of water allocation between water users is expanding largely, including irrigation as the largest user, while the density of headworks in the river are getting higher. Considering that water is limited, the practice of irrigation water allocation needs to be refined, from the traditional equity to volumetric equity. MEQAA (Model Equalisasi Alokasi Air/Equalization Model of Water Allocation) plays a role in determining water sharing between headworks in order to meet the maximum-equal K-factor in river. MEQAA-Generic is a calculation machine with: analog-deterministic dynamic model; network equation according to mass balance and linear optimization; independent-based system; sustainability-efficiency-equity constraints; Ms. Excel-VBA. The inputs are: scheme system, local inflow, and irrigation demand. The outputs are: K-factor, release and ecosystem quote. The model performance is identified by comparing the output to the class of K-factor based on treatment of water distribution. The model test is performed in an uncontrolled and complicated system in Kukusan Tanggek watershed with 24 headworks in Lombok river basin. As long as it is adequate for water sharing, MEQAA-G can always produce maximum-equal K-factor. The output model is used to operation control.
\end{abstract}

\section{Introduction}

System is a collective work between components for a particular purpose [3]. Since every main structure node of water withdrawal (headwork/HW) in the river is hydraulic-gravity connected as a system unit, therefore one integrated management is needed [32]. Water withdrawal must be based on a proportional, efficient, and equitable water allocation plans [13], considering in Indonesia water is public goods, and limited.

Practically, water allocation is not based on system, and disoriented, resulting in inequity [22]. Water allocation gap occurs mostly in water deficit areas, resulting in conflicts [12], [25], and [27]. In [26], competition case between water users in South Bali were caused by irrigation water deficit which makes it a complicated task. Regarding to domination of irrigation (usage rate over 90\%) [7], this sector needs to be controlled. This effort is aligned with the emphasis of equity in water allocation by IWRM (Integrated Water Resources management) [29].

To create equity, a proportional water sharing is needed [8], [9], [12], and [25]. In [11], proportional equalization is an equal $\mathrm{K}$-factor (release demand ratio) between same users. Also, K-factor method in Indonesia has been known in irrigation operations since the Dutch era. K-factor indicates volumetric reliability in system
[16], which is Release Demand Ratio (RDR) [5], [4], [11], and [30].

Inequity due to the failure of water sharing will trigger conflict, even threaten food security [18]. Inequity also hit the ecosystem. For ecosystems, rules are required and must be taken as other water demands in the calculation [17]. The rule of ecosystem allotment is regulated in Government Regulation RI No. 38 Year 2011 regarding River, $95 \%$ probability of water availability and $5 \%$ of water availability (Directorate General of Water Resources RI, Irrigation Planning Criteria or KP-02revised edition, 2013: 28).

Water allocation control between nodes (headwork) in the complex river systems should be supported by models, such as Decision Support System (DSS) [11]. However, DSS produces many alternatives, other than optimal solutions, that professionals are required to make decisions [3]. From a series of DSS models in Table 1, upon local models it can be concluded as follows: i) limited ability in rigid systems, ii) does not consider ecosystems, and iii) does not produce water release according to volumetric equity. Besides, upon import models, it can be summarized that: i) priority oriented (with penalty), thus not suitable in Indonesia, and ii) integrated hydrology/water quality model.

Alternative model is expected to work multisystem. The output of the model has to fulfill the triangle constraints of sustainability-efficiency-equity [22] or SEE.

anangmf62@gmail.com 
Table 1. Recapitulation of water allocation model

\begin{tabular}{|c|c|c|c|c|c|c|c|}
\hline No & $\begin{array}{l}\text { Model/Origin/ } \\
\text { Year }\end{array}$ & $\begin{array}{l}\text { Programming } \\
\text { Language }\end{array}$ & $\begin{array}{l}\text { Orientation/ } \\
\text { Function }\end{array}$ & $\begin{array}{l}\text { Integrated } \\
\text { Analysis }\end{array}$ & $\begin{array}{l}\text { Type/Scale/ } \\
\text { Type of Nodes }\end{array}$ & Result & Negotiaton \\
\hline 1 & $\begin{array}{l}\text { HLD/ } \\
\text { LOMBOK RB/ } \\
\text { England Expert/ } \\
1991\end{array}$ & Fortran & $\begin{array}{l}\text { Equality / } \\
\text { crop production, } \\
\text { real time }\end{array}$ & Hydrology & $\begin{array}{l}\text { Specific, scheme } \\
\text { (interdependent), } \\
\text { Limited nodes, } \\
\text { Diversion \& reservoir }\end{array}$ & $\begin{array}{l}\text { Release, } \\
\text { Unequal K-factor }\end{array}$ & Yes \\
\hline 2 & $\begin{array}{l}\text { MS EXCEL } \\
\text { MODEL/ } \\
\text { Indonesia/ } \\
1998 \& 2006\end{array}$ & $\begin{array}{l}\text { Lotus } 123 \\
\text { and } \\
\text { Excel-VBA }\end{array}$ & $\begin{array}{l}\text { Equality, } \\
\text { real time }\end{array}$ & No & $\begin{array}{l}\text { Specific, simple } \\
\text { scheme, } \\
\text { Very limited nodes, } \\
\text { Diversion }\end{array}$ & $\begin{array}{l}\text { Release, } \\
\text { Unequal K-factor }\end{array}$ & Yes \\
\hline 3 & $\begin{array}{l}\text { PAA/ } \\
\text { Indonesia/ } \\
2010\end{array}$ & Excel & $\begin{array}{l}\text { Equality, } \\
\text { real time }\end{array}$ & $\begin{array}{l}\text { Irrigation water } \\
\text { demand }\end{array}$ & $\begin{array}{l}\text { Specific, simple } \\
\text { scheme, } \\
\text { Very limited nodes, } \\
\text { Diversion }\end{array}$ & $\begin{array}{l}\text { Water balance, } \\
\text { Operation rule } \\
\text { "adjusted" }\end{array}$ & Yes \\
\hline 4 & $\begin{array}{l}\text { WRMM/ } \\
\text { Canada/ } \\
1981 \\
\end{array}$ & Visual Basic & $\begin{array}{l}\text { Priority, } \\
\text { planning }\end{array}$ & Hydrology & $\begin{array}{l}\text { Generic, watershed, } \\
\text { Diversion \& reservoir }\end{array}$ & Water balance & Yes \\
\hline 5 & $\begin{array}{l}\text { RIBASIM/ } \\
\text { Delft-Belanda/ } \\
1985\end{array}$ & Fortran & $\begin{array}{l}\text { Priority, } \\
\text { planning }\end{array}$ & $\begin{array}{l}\text { Hydrology \& } \\
\text { water quality }\end{array}$ & $\begin{array}{l}\text { Generic, watershed, } \\
\text { Limited nodes, } \\
\text { Diversion \& reservoir }\end{array}$ & Water balance & Yes \\
\hline 6 & $\begin{array}{l}\text { REALM/ } \\
\text { Australia/ } \\
\text { 1980th }\end{array}$ & Fortran & $\begin{array}{l}\text { Priority, } \\
\text { planning }\end{array}$ & $\begin{array}{l}\text { Hydrology \& } \\
\text { water quality }\end{array}$ & $\begin{array}{l}\text { Generic, } \\
\text { scheme, } \\
\text { Nodes }>>>\text {, } \\
\text { Diversion \& reservoir }\end{array}$ & Water balance & Yes \\
\hline 7 & $\begin{array}{l}\text { WRAP/ } \\
\text { Texas-USACE/ } \\
\text { 1980th }\end{array}$ & Fortran & $\begin{array}{l}\text { Priority, } \\
\text { planning }\end{array}$ & $\begin{array}{l}\text { Hydrology \& } \\
\text { water quality }\end{array}$ & $\begin{array}{l}\text { Generic, watershed, } \\
\text { Nodes }>>>, \\
\text { Diversion \& reservoir }\end{array}$ & Water balance & Yes \\
\hline 8 & $\begin{array}{l}\text { WEAP/ } \\
\text { SEI-Swedia/ } \\
\text { 2000th }\end{array}$ & Javascript & $\begin{array}{l}\text { Priority, } \\
\text { planning }\end{array}$ & $\begin{array}{l}\text { Hydrology \& } \\
\text { water quality }\end{array}$ & $\begin{array}{l}\text { Generic, watershed, } \\
\text { Diversion \& reservoir }\end{array}$ & Water balance & Yes \\
\hline 9 & $\begin{array}{l}\text { MIKE BASIN/ } \\
\text { DHI-Denmark/ } \\
2008\end{array}$ & $\begin{array}{l}\text { Link with } \\
\text { Excel- } \\
\text { Visual Basic }\end{array}$ & $\begin{array}{l}\text { Priority, equally } \\
\text { deficit, and crop } \\
\text { stress. } \\
\text { Planning }\end{array}$ & $\begin{array}{l}\text { Hydrology, } \\
\text { groundwater, \& } \\
\text { water quality }\end{array}$ & $\begin{array}{l}\text { Generic, watershed, } \\
\text { Diversion \& reservoir }\end{array}$ & Water balance & Yes \\
\hline
\end{tabular}

If water is public goods, then "equal for equity" will be accomplished by MEQAA-G. The target of the model is maximum-equal $\mathrm{K}$-factor which is to allocate water proportionally, efficiently, and equally between HW in the system. In the beginning, this model was called MEQAA-E (Embryo), a conceptual model with a linear simulation-optimization based on mass balance equation.

The optimization concepts of MEQAA-E [5] is: i) to control the utilization of local inflow [23], ii) based on node in independent system [14] and [2], and iii) refers to the principle of mass balance [30] and [9]. Based on the concepts, linear network equation (NE) can be formed according to the system configuration. [5] continued, MEQAA-E's experiment used system scheme and hypothetical data, with NE being arranged manually, resulting in: i) max-equal $\mathrm{K}$-factor between same users (irrigation), ii) SEE constraints are fulfilled, and iii) policy rules about K-factor gap between wet-dry system can be applied.

MEQAA-E's ability is limited and prone to human errors if it applied in various independent system states. The current research is the development of MEQAA-E to MEQAA-G (Generic). Generic model applies multisystem [20] and [30]. The principle of K-factor equalization of MEQAA-G follows MEQAA-E. The difference is MEQAA-G automatically builds up a specific model according to system scheme on Excel sheet.

Since MEQAA-E/G is conceptual, the validity of the model is determined based on the theory and assumptions used to construct the model structure [3]. With input variability in the form of system scheme, and also inflow and demand value, it is expected that every specific model formed by MEQAA-G in specific system can produce the optimal output.

As long as water can be allocated based on gravity flow water system, MEQAA-G will produce max-equal $\mathrm{K}$-factor or equal $\mathrm{K}$-factor class. Output model is used to control water allocation proportionally, efficiently, and equally between $\mathrm{HW}$ of same users (irrigation) in the river system.

\section{Study Area}

Lombok River Basin (RB) in Fig. $2\left(4.738\right.$ km² $^{2}, 3.5$ million populations, rainy season Nov-Mar, dry season Apr-Oct, normal rain 1189-1505 mm) with irrigation as the dominant user (94\%) with system capacity in Table 2. High Level Diversion (HLD) suppletion canal was built in the 1980s to distribute water from the wet watershed in the west Lombok to dry watershed in the middle-eastsouth with 92 nodes in 6 watersheds interconnection for 60.000 ha of irrigation areas (Kartabrata \& Marjanto, 1994: 40). And today, in HLD interconnection with 398 nodes in 12 watersheds for more than 97.000 ha [33].

Meanwhile, Kukusan Tanggek watershed is a dependent system $\left(185 \mathrm{~km}^{2}\right.$, density of 1 node $/ 5 \mathrm{~km}^{2}, 30$ units of weir, 1 unit of small reservoir (local name is embung), 6446 ha of irrigation areas, 2 units of 30 lt/s of water domestic). 
Table 2. Capacity of water resources system in Lombok RB.

\begin{tabular}{|c|c|c|c|c|}
\hline No & Item & Unit & Independent & Interdependent \\
\hline 1 & Total watersheds & unit & 40 & 12 \\
\hline 2 & $\begin{array}{l}\text { Total area of } \\
\text { effective } \\
\text { watersheds }\end{array}$ & $\mathrm{km}^{2}$ & 1.152 & 1.454 \\
\hline 3 & $\begin{array}{ll}\text { Total nodes: } \\
-\quad \text { Weir } \\
-\quad \text { Small reservoir } \\
\text { (embung) } \\
-\quad \text { Reservoir } \\
-\quad & \text { Diversion in } \\
& \text { HLD canal } \\
\end{array}$ & unit & $\begin{array}{c}145 \\
118 \\
27 \\
-\end{array}$ & $\begin{array}{c}371 \\
308 \\
60 \\
3 \\
60\end{array}$ \\
\hline 4 & Node density & $\begin{array}{l}\text { unit/ } \\
\mathrm{km}^{2}\end{array}$ & 0.13 & 0.26 \\
\hline 5 & $\begin{array}{l}\text { Total irrigation } \\
\text { area }\end{array}$ & ha & 26.221 & 97.037 \\
\hline
\end{tabular}

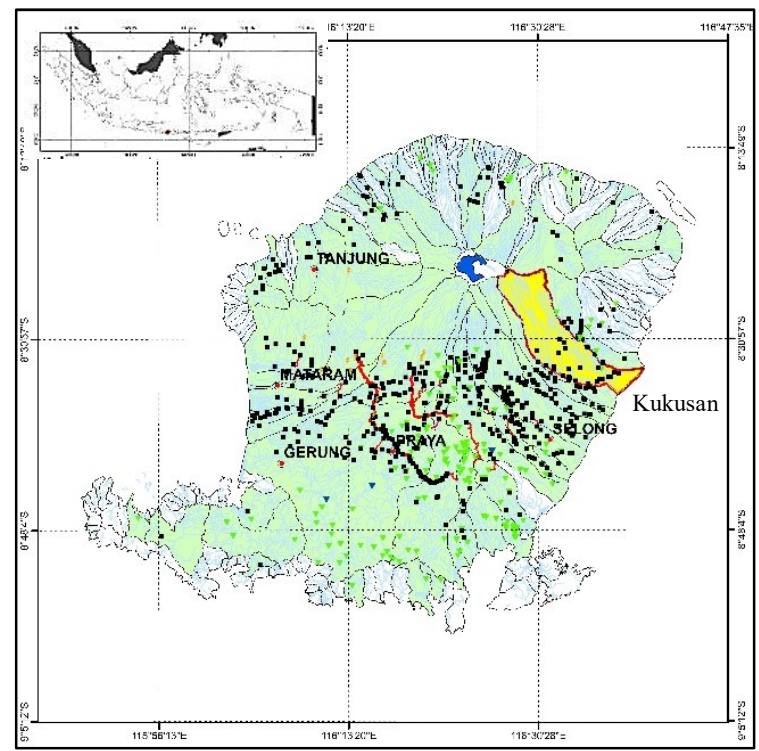

Fig. 2. Distribution of instream irrigation-headwork in Lombok RB and research site

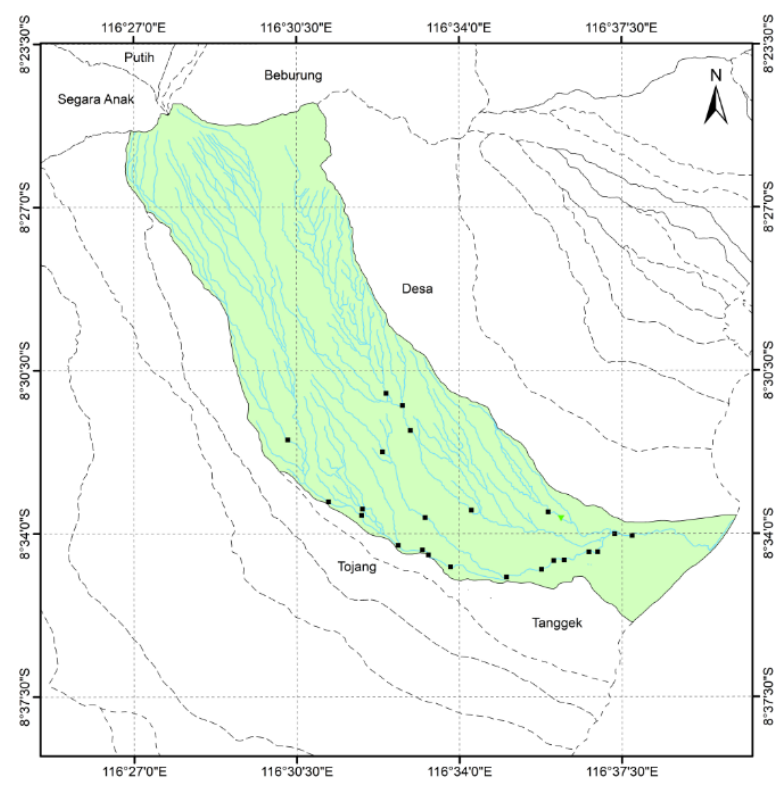

Fig. 3. Kukusan Tanggek watershed
The deficit of irrigation water in Lombok $R B$ is caused by continuity and uneven distribution of water potential [21]. National rice granary areas, such as Lampung, Sulawesi Selatan, Bali and Lombok are experiencing high water vulnerability [10]. Based on the survey of water distribution in irrigation areas in Lombok RB (March IV and May I 2016, crop pattern: paddy (P) and paddy-soybean (P-S), in 114 nodes in 14 main rivers), there are: i) inequity in dry watershed, and ii) $\mathrm{K}$-factor in the upstream is $\mathrm{K} 1 / \mathrm{K} 2$, while in the downstream is deficit. The gap is in sync with [27], that in Lombok RB there are 386 conflict cases/year between water users, and drag the government as one of its actors. The gap occurs in Kukusan Tanggek as shows in Table 3.

Table 3. Cass of K-factor in the main river of Kukusan Tanggek

\begin{tabular}{|c|c|c|c|c|c|c|}
\hline \multirow{2}{*}{ Headwork } & \multirow{2}{*}{$\begin{array}{c}\text { Irrigation } \\
\text { Area } \\
\text { (ha) }\end{array}$} & \multirow{2}{*}{$\begin{array}{l}\text { Crop } \\
\text { Start }\end{array}$} & \multirow{2}{*}{$\begin{array}{l}\text { Crop } \\
\text { Pattern }\end{array}$} & \multirow{2}{*}{$\begin{array}{l}\text { Crop } \\
\text { Area } \\
\text { (ha) }\end{array}$} & \multicolumn{2}{|c|}{$\begin{array}{c}\text { Class of } \\
\text { K-Factor }\end{array}$} \\
\hline & & & & & $\begin{array}{l}\text { Mar } \\
\text { IV }\end{array}$ & $\begin{array}{c}\text { May } \\
\text { I }\end{array}$ \\
\hline B Meloang & 168 & Sep II & P-S & 162 & K1 & $\mathrm{K} 2$ \\
\hline B Madang 1 & 138 & Sep II & P-S & 130 & K1 & $\mathrm{K} 2$ \\
\hline B Madang 2 & 46 & Sep II & $\mathrm{P}$ & 46 & K1 & $\mathrm{K} 2$ \\
\hline B Bagek Nyake & 189 & Okt II & P-S & 172 & K2 & K2 \\
\hline B Mamben & 477 & Okt II & P-S & 453 & $\mathrm{~K} 2$ & $\mathrm{~K} 2$ \\
\hline B Kukusan & 1117 & Okt II & P-S & 1055 & $\mathrm{~K} 2$ & $\mathrm{~K} 2$ \\
\hline B Jowet & 100 & Okt II & P-S & 96 & K2 & $\mathrm{K} 2$ \\
\hline B Tegaron & 202 & Okt II & P-S & 192 & K2 & K2 \\
\hline B Reban Aji & 129 & Okt II & P-S & 124 & K3 & K2 \\
\hline B Kerumut & 58 & Okt II & $\mathrm{P}$ & 58 & K3 & $\mathrm{K} 2$ \\
\hline B Sukamulia & 513 & Okt II & P-S & 480 & K3 & K3 \\
\hline B Batu Yang & 532 & Okt I & P-S & 517 & $\mathrm{~K} 2$ & $\mathrm{~K} 2$ \\
\hline
\end{tabular}

\section{Method}

\subsection{Equalization Method}

Water distribution between HWs need to be controlled, considering that water is limited and unequal. Gravitationally, water in the upstream is allocated to the downstream due to their own needs so K-factor gap does not happen, surely with emphasis on SEE constraints. Kfactor could not be measured, therefore K-factor class which is analogized based on water distribution pattern in irrigation area is used. Practically, K-factor class is influnced by the adequacy of water supply and affects the inter-block rotation within the irrigation areas.

Table 4. Optimization constraint within MEQAA-G

\begin{tabular}{|c|c|c|c|}
\hline & Sustainability & Efficiency & Equity \\
\hline Indicator & 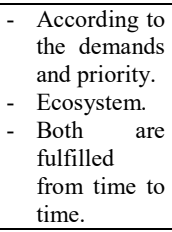 & $\begin{array}{l}\text { - Water release } \\
\text { does not exceed } \\
\text { the water demand. } \\
\text { - Minimum water } \\
\text { sharing is as much } \\
\text { as the ecosystem } \\
\text { allotment. }\end{array}$ & $\begin{array}{l}\text { Equal K-factor } \\
\text { between the } \\
\text { same users after } \\
\text { the fulfillment } \\
\text { of domestic and } \\
\text { ecosystem } \\
\text { needs. }\end{array}$ \\
\hline Goal & \multicolumn{3}{|c|}{$\begin{array}{l}\text { To maximize water release proportionally, } \\
\text { equally between the same users (max-equal K-factor) }\end{array}$} \\
\hline
\end{tabular}

K-factor class in Table 5 was inspired by [1], [4], [28] and Minesterial Regulation PU-PERA No. 12/PRT/M/2015). This K-factor's class classification 
considers inflow fluctuations, weir/diversion dominance, operational intensity, and error measuring tool.

Table 5. K-factor class of irrigation

\begin{tabular}{ccccc}
\hline Class & $\begin{array}{c}\text { Range of } \\
\text { K-Factor } \\
(\%)\end{array}$ & $\begin{array}{c}\text { Water } \\
\text { Deficit }\end{array}$ & $\begin{array}{c}\text { Operational } \\
\text { Categories }\end{array}$ & $\begin{array}{c}\text { Interlude of } \\
\text { Water Distribution }\end{array}$ \\
\hline K1* & 100 & - & Continuously & - \\
\hline K1 & $80-99$ & $\begin{array}{c}\text { Very } \\
\text { low }\end{array}$ & $\begin{array}{c}\text { Continuously } \\
\text { (limited) }\end{array}$ & - \\
\hline K2 & $60-79$ & Low & Rotation (low) & Short \\
\hline K3 & $40-59$ & Medium & $\begin{array}{c}\text { Rotation } \\
\text { (medium) }\end{array}$ & Medium \\
\hline K4 & $20-39$ & High & Rotation (high) & Long \\
\hline $\mathrm{E}$ & $<20$ & $\begin{array}{c}\text { Very } \\
\text { high }\end{array}$ & Emergency & $\begin{array}{c}\text { Withered crop is } \\
\text { prioritized }\end{array}$ \\
\hline
\end{tabular}

\subsection{Model Structure}

The purpose of water allocation is to distribute water optimally between nodes in the system [9]. For that purpose, MEQAA-G was built with characteristics of: i) as a "calculating machine" of water allocation with a maxequal K-factor, after drinking water and ecosystem are fulfilled [23], dan ii) using the technique of "tracking" system scheme to create NE. MEQAA-G is supported by Excel-VBA, because it is popular/practical for nonprofessional programmers and its code format is relative simple to run such a great program [28].

Solutions on water resources system are often using optimization [9], [23], [24] and [30], such as linear programming (LP). In [9], [15], [20] and [30], optimation/simulation model is used to attain system operation decisions. In [24] both combinations produce an optimal solution, although it contains many variables. Concluded by [30], optimal/nearly optimal value is obtained from execution of ad hoc model with iteration. Iteration requires a set up initial value [9], which is $\mathrm{K}$ factor draft $100 \%-0$ with step $0,1-1 \%$ [5].

The principle of mass balance [9], [30], [31] in every $\mathrm{HW}$ is: with the number on the right-hand side.

$$
\mathrm{I}-\mathrm{O}=\Delta \mathrm{V}
$$

With inflow (I) includes local inflow (QL) and water sharing $(\mathrm{QS})$ from upstream, outflow $(\mathrm{O})$ includes release (QR) and water sharing (QS) to downstream, and $\Delta \mathrm{V}=\mathrm{a}$ change in volume. It is assumed that the loss of water (LL) between HWs mutually negates with return flow (RF) from irrigation area. The loss value is hard to quantify therefore it is often ignored [30].

MEQAA-G with its purpose of maximizing water distribution is:

$$
\max \mathrm{Z}=\sum_{\mathrm{i}=1}^{\mathrm{n}} \mathrm{K}_{\mathrm{i}} \cdot \mathrm{QD}_{\mathrm{i}}
$$

If every $\mathrm{HW}$ is weir/diversion, then $\Delta \mathrm{V}=0$ [30]. Based on formula 1 and 2, NE is arranged based on independent system. NE follows domino effect flow [30] and [2]. The simple structure of NE as shown in Figure 3 combines 5 functions of constraint, such as:

- $\quad$ mass balance: $\mathrm{QL}_{\mathrm{i}}+\mathrm{QS}_{\mathrm{i}-1}-\mathrm{QR}_{\mathrm{i}}-\mathrm{QS}_{\mathrm{i}}=0$
- water availability: $0 \leq \mathrm{QR}_{\mathrm{i}} \leq\left(\mathrm{QL}_{\mathrm{i}}+\mathrm{QS}_{\mathrm{i}+1}-\mathrm{QE}_{\mathrm{i}}\right)$

- ecosystem sustainability: $\mathrm{QS}_{\mathrm{i}} \geq \mathrm{QE}_{\mathrm{i}}$ with

$$
\mathrm{QE}=0.05 \mathrm{QA}
$$

- efficiency: $0 \leq \mathrm{QR}_{\mathrm{i}} \leq \mathrm{QD}_{\mathrm{i}}$ which can substituted into $0 \leq \mathrm{K}_{\mathrm{i}} \leq 1$ or $\mathrm{QR}_{\mathrm{i}}=\mathrm{K}_{\mathrm{i}}$. QD $\mathrm{QD}_{\mathrm{i}}[5]$

- equity from upstream to downstream of HW:

$$
\mathrm{K}_{\mathrm{i}}-\mathrm{K}_{\mathrm{i}+1}=0 \text { [5] }
$$

$\mathrm{QD}=$ irrigation demand, $\mathrm{QE}=$ ecosystem allocation

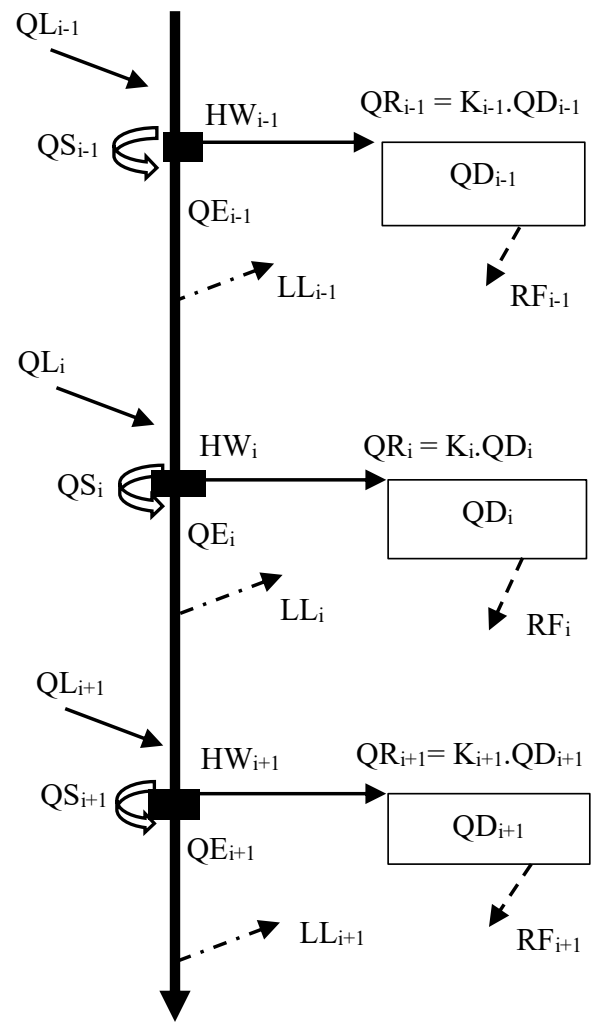

Fig. 3. Network flow sketch in system segment with weir

As for reservoir $(\Delta \mathrm{V} \neq 0)$, volume calculation is applied [30], [6] and [31]:

$$
\mathrm{V}_{\text {end }}=\mathrm{V}_{\text {beg }}+\mathrm{V}_{\text {inlfow }}-\mathrm{V}_{\text {release }}-\mathrm{WL}
$$

With $0 \leq \mathrm{V}_{\text {end }} \leq \mathrm{V}_{\text {eff, }}, \mathrm{V}_{\text {eff }}=$ effective volume and $\mathrm{WL}$ = water loss because of evaporation and seepage. Since in Kukusan Tanggek system there is Embung Senang, therefore reservoir rule curve is required as constraint adjusment factor [31]. Operational volume limit is:

$\mathrm{VRC}=\mathrm{V}_{\text {beg }} * \mathrm{RCC}$ on condition that $\mathrm{V}_{\text {end }} \geq \mathrm{VRC}$

Regarding to formula 8, rule curve coeficient $(0 \leq$ $\mathrm{RCC} \leq 1)$ is spesific in every reservoir. This coefficient is based on inflow-demand, reservoir capacity and operating policy. In this study, the equation of RCC line is assumed to follow functional equation of Batujai reservoir.

For more practical [33], WL $\left(=0.01 . \mathrm{V}_{\text {beg }}\right)$ is assumed to be $1 \%$ of the beginning volume of Batujai Reservoir 
$\left(\mathrm{V}_{\text {eff }}=18.000 .000 \mathrm{~m}^{3}\right.$, with evaporation of 4-6 mm/day and seepage of $0.08-0.70 \mathrm{lt} / \mathrm{s}$ ).

NE's development applies the numbering of streams and juctions respectively such as main river 100, and tributary 200, 300 and so on, while for junction number is $\{($ tributary number: 100) -1$\}$ (Figure 5). The output of model performance test will prove that the field conditions is uncontrolled, which means existing $\mathrm{K}$-factor class is unequal between upstream and downstream.

In MEQAA-G, there is about 1000 lines of syntax code, including: i) tracking (including NE) and ii) equalization. Trial of the code uses hypothetical data, including river scheme, inflow, dan demand.

\section{Results and Discussion}

\subsection{System scheme tracking}

In Figure 5, there are: i) $24 \mathrm{HWs}$ with B code for 23 weirs/diversions and EM code for 1 small reservoir, ii) number 100 in the main river, then number $200-500$ in every branch river, and iii) junction number 1 at tributary 200, 2 at 300, etc.

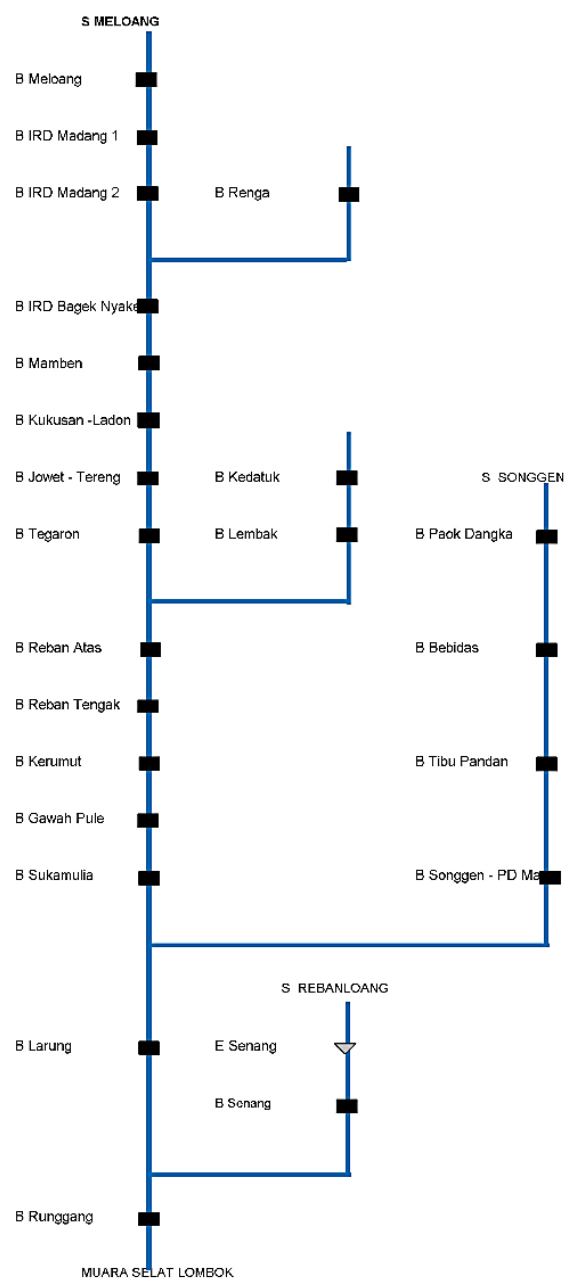

Fig. 5. Node codes of HW and junction in Kukusan Tanggek system scheme

\subsection{River group and network equation structure}

Based on system scheme track (Figure 5), the model automatically produces river grouping (Table 6). In this case, there are 5 river groups with numbers 100-500 (Table 6). NE structure is on the Excel sheet (Table 7), generally described that: i) NE translates the mass balance principles and optimation that detailed into 3 to 10 equations to form computational equations in every $\mathrm{HW}$, ii) If a HW has demand $=0$, then link of gap will go towards HW in the downstream, and iii) there is no link of gap in the most downstream HW, due to the estuary.

Table 6. River grouping

\begin{tabular}{|c|c|c|c||c|}
\hline \multicolumn{1}{|c|}{43} & 48 & 53 & 58 & 63 \\
\hline & & & & \\
\hline RIV_100 & RIV_200 & RIV_300 & RIV_400 & RIV_500 \\
\hline B MELOANG & B RENGA & B KEDATUK & B PAOK DANGKA & EM SENANG \\
\hline B MADANG 1 & B BAGEK NYAKE & B LEMBAK & B BEBIDAS & B SENANG \\
\hline B MADANG 2 & B MAMBEN & B REBAN ATAS & B TIBU PANDAN & B RUNGGANG \\
\hline B BAGEK NYAKE & B KUKUSAN-LADON & B REBAN TENGAK & B SONGGEN-PDMARE & \\
\hline B MAMBEN & B JOWET-TERENG & B KERMUT & B LARUNG & \\
\hline B KUKUSAN-LADON & B TEGARON & B GAWAH PULE & B RUNGGANG & \\
\hline B JOWET-TERENG & B REBAN ATAS & B SUKAMULIA & & \\
\hline B TEGARON & B REBAN TENGAK & B LARUNG & & \\
\hline B REBAN ATAS & B KERMUT & B RUNGGANG & & \\
\hline B REBAN TENGAK & B GAWAH PULE & & & \\
\hline B KERMUT & B SUKAMULIA & & & \\
\hline B GAWAH PULE & B LARUNG & & & \\
\hline B SUKAMULIA & BRUNGGANG & & & \\
\hline B LARUNG & & & & \\
\hline B RUNGGANG & & & & \\
\hline & & & & \\
\hline
\end{tabular}


Table 7. Some specific MEQAA-G worksheeet format in Kukusan Tanggek system
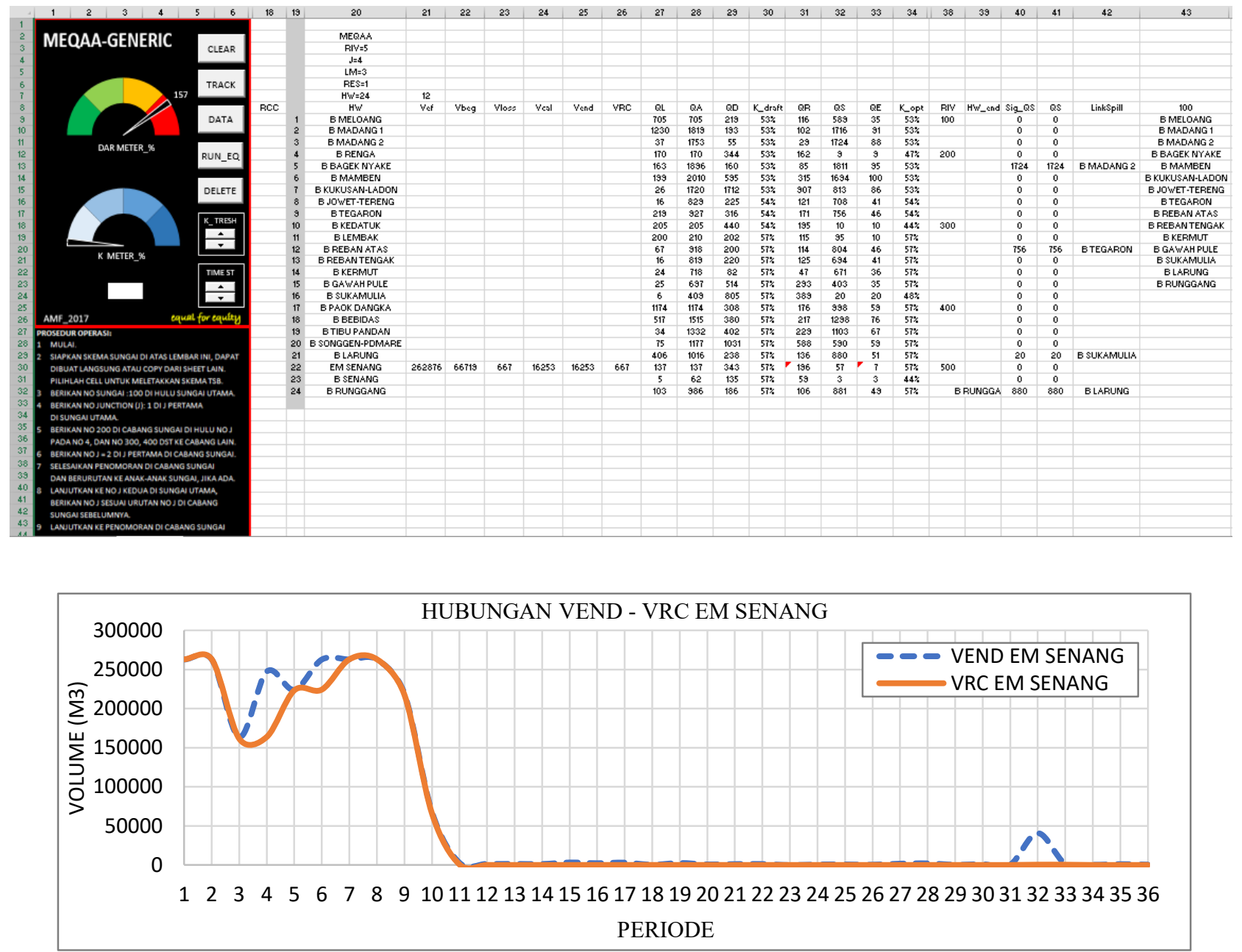

Fig. 5. Vend and VRC of Senang Small Reservoir

\subsection{Result and discussion}

Based on the input data of QL and QD (Table 8), MEQAA-G output is obtained as shown in Table 9 (Kfactor) dan Figure 6a and 6b. It is generally described: i) on trial with hypothetical data and ends with secondary data of 36 periods of inflow and demand, there is ouput model with release that is compatible with max-equal $\mathrm{K}$ factor, ii) K-factor value is strongly influenced by inflow, iii) spillout/water sharing is always the same as or more than the ecosystem rations, iv) water sharing from Senang small reservoir (embung) to Senang Weir can be controlled ( $\left.\mathrm{V}_{\text {end }} \geq \mathrm{VRC}\right)$, and $\mathrm{v}$ ) if the inflow is high, then the iteration will be fast, and vice versa. In this case, there are about $1.298-844.240$ iteration (K-factor's step $=$ $0.1 \%$ ), with total time around 7 minutes.
Table 8. Some local inflow (QL, lt/s) and irrigation demand (QD, lt/s) data

\begin{tabular}{|cccccc|}
\hline \multirow{2}{*}{ NO } & HEADWORK & QL & QD & QL & QD \\
\cline { 3 - 6 } & & JAN I & JAN I & JUL I & JUL I \\
\hline 1 & B MELOANG & 1057 & 0 & 337 & 99 \\
2 & B MADANG 1 & 1849 & 0 & 588 & 22 \\
3 & B MADANG 2 & 62 & 0 & 18 & 6 \\
4 & B RENGA & 270 & 0 & 82 & 160 \\
5 & B BAGEK NYAKE & 267 & 0 & 78 & 103 \\
6 & B MAMBEN & 332 & 0 & 95 & 402 \\
7 & B KUKUSAN-LADON & 49 & 11 & 13 & 1146 \\
8 & B JOWET-TERENG & 31 & 27 & 8 & 172 \\
9 & B TEGARON & 418 & 40 & 105 & 252 \\
10 & B KEDATUK & 304 & 34 & 98 & 267 \\
11 & B LEMBAK & 325 & 20 & 95 & 140 \\
12 & B REBAN ATAS & 132 & 25 & 32 & 161 \\
13 & B REBAN TENGAK & 31 & 30 & 7 & 183 \\
14 & B KERMUT & 48 & 11 & 11 & 68 \\
15 & B GAWAH PULE & 52 & 71 & 12 & 444 \\
16 & B SUKAMULIA & 12 & 84 & 3 & 581 \\
17 & B PAOK DANGKA & 1713 & 0 & 561 & 153 \\
18 & B BEBIDAS & 746 & 0 & 247 & 193 \\
19 & B TIBU PANDAN & 50 & 0 & 16 & 236 \\
20 & B SONGGEN-PD MARE & 125 & 58 & 52 & 736 \\
21 & B LARUNG & 698 & 0 & 283 & 165 \\
22 & EM SENANG & 236 & 0 & 96 & 252 \\
23 & B SENANG & 10 & 0 & 4 & 94 \\
24 & B RUNGGANG & 194 & 0 & 72 & 134 \\
\hline
\end{tabular}


Table 9 shows some model outputs ( 8 of 36 periods), referring to equal $\mathrm{K}$-factor in every river group. The flow follows hydraulic link from HW in the upstream to HW in the downstream in each river. Downstream in river 100 will experience more than once equalization, due to its part of many rivers $(200-500)$ as shown in Table 6 . Under conditions of demand $=0$ for the period of Jan I and Oct III (Table 9), it is written "FALSE" which means the HW is not included in the calculation of the K-factor gap (grey colour in Figure 6a). The calculation of gap is forwarded to the downstream $\mathrm{HW}$.

In Figure 5, $\mathrm{V}_{\text {end }} \geq \mathrm{VRC}$ is fulfilled. $\mathrm{RCC}=100 \%$ occurred in Jan 1 (rainy season) that the reservoir was full. Menwhile, in Apr I - Des III (dry season), $\mathrm{RCC}=1 \%$, the volume reservoir was minimum $(\approx 0)$.

Table 9. Some MEQAA-G output (K factor)

\begin{tabular}{|cccccccccc|}
\hline \multirow{2}{*}{ NO } & \multirow{2}{*}{ HEADWORK } & 1 & 3 & 10 & 12 & 19 & 21 & 28 & 30 \\
\cline { 3 - 9 } & & JANI & JAN III & APR I & APR III & JUL I & JUL III & OKT I & OKT III \\
\hline 1 & B MELOANG & FALSE & $100 \%$ & $88 \%$ & $53 \%$ & $37 \%$ & $55 \%$ & $14 \%$ & $14 \%$ \\
2 & B MADANG 1 & FALSE & $100 \%$ & $88 \%$ & $53 \%$ & $37 \%$ & $55 \%$ & $14 \%$ & FALSE \\
3 & B MADANG 2 & FALSE & $100 \%$ & $88 \%$ & $53 \%$ & $37 \%$ & $55 \%$ & $14 \%$ & FALSE \\
4 & B RENGA & FALSE & $100 \%$ & $88 \%$ & $47 \%$ & $37 \%$ & $41 \%$ & $11 \%$ & $14 \%$ \\
5 & B BAGEK NYAKE & FALSE & $100 \%$ & $88 \%$ & $53 \%$ & $37 \%$ & $55 \%$ & $14 \%$ & $14 \%$ \\
6 & B MAMBEN & FALSE & $100 \%$ & $88 \%$ & $53 \%$ & $37 \%$ & $55 \%$ & $14 \%$ & $14 \%$ \\
7 & B KUKUSAN-LADON & $100 \%$ & $100 \%$ & $88 \%$ & $53 \%$ & $37 \%$ & $55 \%$ & $14 \%$ & $14 \%$ \\
8 & B JOWET-TERENG & $100 \%$ & $100 \%$ & $88 \%$ & $54 \%$ & $38 \%$ & $55 \%$ & $15 \%$ & $14 \%$ \\
9 & B TEGARON & $100 \%$ & $100 \%$ & $88 \%$ & $54 \%$ & $38 \%$ & $55 \%$ & $15 \%$ & $14 \%$ \\
10 & B KEDATUK & $100 \%$ & $100 \%$ & $88 \%$ & $44 \%$ & $35 \%$ & $49 \%$ & $15 \%$ & $15 \%$ \\
11 & B LEMBAK & $100 \%$ & $100 \%$ & $89 \%$ & $54 \%$ & $38 \%$ & $55 \%$ & $15 \%$ & $15 \%$ \\
12 & B REBAN ATAS & $100 \%$ & $100 \%$ & $89 \%$ & $54 \%$ & $38 \%$ & $55 \%$ & $15 \%$ & $15 \%$ \\
13 & B REBAN TENGAK & $100 \%$ & $100 \%$ & $89 \%$ & $54 \%$ & $38 \%$ & $56 \%$ & $15 \%$ & $15 \%$ \\
14 & B KERMUT & $100 \%$ & $100 \%$ & $89 \%$ & $54 \%$ & $38 \%$ & $56 \%$ & $15 \%$ & $15 \%$ \\
15 & B GAWAH PULE & $100 \%$ & $100 \%$ & $89 \%$ & $54 \%$ & $38 \%$ & $56 \%$ & $15 \%$ & $15 \%$ \\
16 & B SUKAMULIA & $100 \%$ & $100 \%$ & $88 \%$ & $53 \%$ & $38 \%$ & $55 \%$ & $14 \%$ & $14 \%$ \\
17 & B PAOK DANGKA & FALSE & $100 \%$ & $100 \%$ & $83 \%$ & $65 \%$ & $95 \%$ & $22 \%$ & $24 \%$ \\
18 & B BEBIDAS & FALSE & $100 \%$ & $100 \%$ & $83 \%$ & $65 \%$ & $95 \%$ & $22 \%$ & $24 \%$ \\
19 & B TIBU PANDAN & FALSE & $100 \%$ & $100 \%$ & $83 \%$ & $65 \%$ & $96 \%$ & $22 \%$ & $24 \%$ \\
20 & B SONGGEN-PD MARE & $100 \%$ & $100 \%$ & $100 \%$ & $82 \%$ & $64 \%$ & $95 \%$ & $21 \%$ & $23 \%$ \\
21 & B LARUNG & FALSE & $100 \%$ & $100 \%$ & $100 \%$ & $100 \%$ & $100 \%$ & $69 \%$ & $89 \%$ \\
22 & EM SENANG & FALSE & $63 \%$ & $62 \%$ & $30 \%$ & $28 \%$ & $60 \%$ & $21 \%$ & $28 \%$ \\
23 & B SENANG & FALSE & $62 \%$ & $61 \%$ & $29 \%$ & $27 \%$ & $59 \%$ & $20 \%$ & $27 \%$ \\
24 & B RUNGGANG & FALSE & $100 \%$ & $100 \%$ & $100 \%$ & $100 \%$ & $100 \%$ & $68 \%$ & $89 \%$ \\
\hline
\end{tabular}

Still in Table 9, in the period of Oct I and Oct II, there is an equal K-factor with a very small value (11-15\%) or emergency (E). In this condition, it is difficult for the water to flow along the river and also the operations can be hampered. To overcome this, it is necessary to allocate water between irrigation area in the river segment with specific HW. In this on-off system, water allocation has to be prioritized according to crop age or urgent demand. This effort is made to increase the K-factor into class K4 or K3.

Figure $6 \mathrm{a}$ and $6 \mathrm{~b}$ are the examples of output machine for the period of Jan I and Jul I. The colours will be plotted on the scheme, such as grey (HW with demand $=0)$, red (K4), yellow (K3), green (K2), light blue (K1) and dark blue $(\mathrm{K} 1 *)$. These colours are suitable with the equalization results as shown in Table 5 .

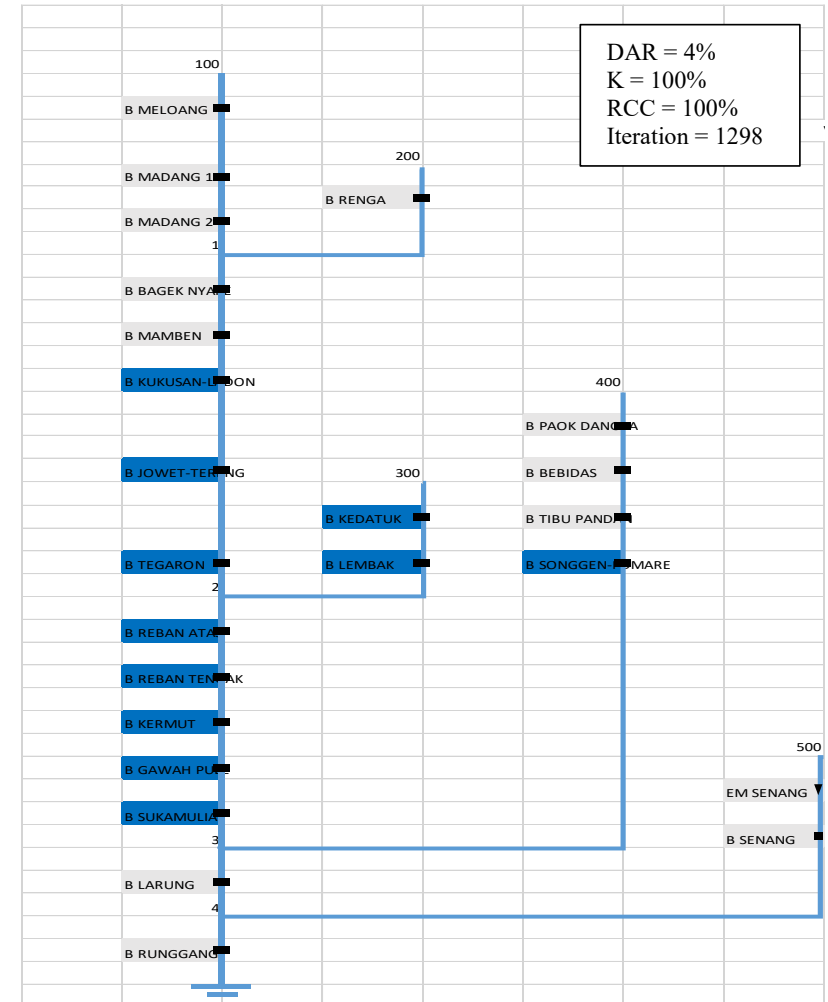

Fig. 6a. Output in Jan I

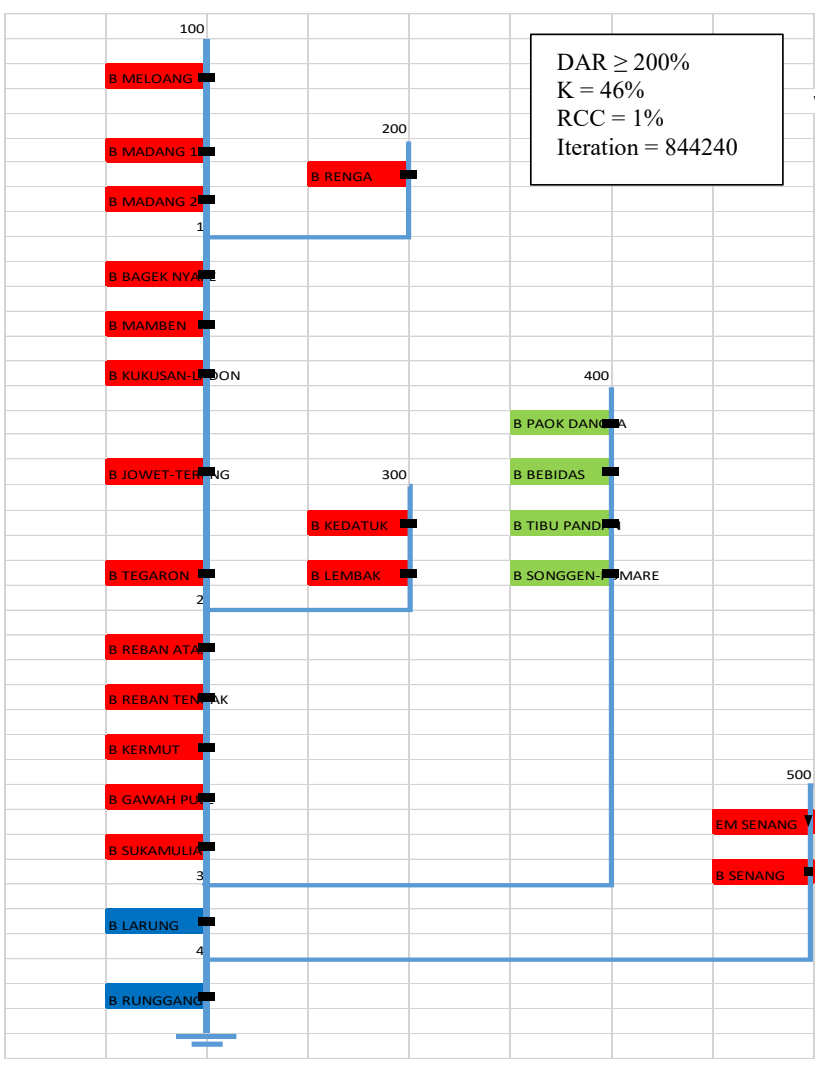

Fig. 6b. Output in Jul I 


\section{Conclusions and recommendation}

Based on the trials in the hypothetical system and Kukusan Tanggek system, it can be concluded and recommended as follows:

1. MEQAA-G simplifies the computation of water allocation in the independent river systems with the final result always meet the max-equal $\mathrm{K}$-factor, and also the ecosystem quota,

2. For the reservoir that produces a result as mentioned above in point a, the water sharing will follow the $V_{\text {end }}$ $\geq$ VRC criteria, with RCC value always varying between operating periods. Rule curve is specific that it always be different in every reservoir.

3. MEGAA-G is not influenced by types of data (hypothetical and or secondary data), since it is a conceptual model and also because NE shapes and links are always dynamic following HW configuration in the system,

4. The number of iterations depends on the density/configuration of HW (including reservoir), water balance and $\mathrm{K}$-factor step,

5. MEQAA-G output is very contrastive with on the field reality (Table 3), i.e. from inequal classification of Kfactor (reality) become equal.

6. It is necessary to make priority on water allocation (on-off system) if K-factor $<20 \%$ (emergency) occurs in some HWs in the system, and

7. MEQAA-G needs to be applied in a more complex independent system with cascade/multi reservoirs or dependent system ( 2 watersheds) to interdependent systems (more than 2 watersheds) in Lombok RB and another.

Thanks are due to individual consultant as youth professional engineer in Water Allocation Unit - Balai Wilayah Sungai Nusa Tenggara I, Lombok River Basin.

\section{References}

1. R. Azuan, AH. Wahyudi, Sobriyah, PKOWDR, Media Teknik Sipil, IX, 71-75 (2009)

2. D. Dutta, S. Kima, J. Vazea, J. Hughesa, A. Yanga, WASWRM, 21st International Congress on Modelling and Simulation. Australia, 2040-2046 (2015)

3. Eriyatno, Ilmu Sistem-Meningkatkan Mutu dan Efektivitas Manajemen, Jilid I E IV (2012)

4. A.M. Fagi, PSDA, Buletin Iptek Tanaman Pangan, 2 No 1, (2007)

5. A.M. Farriansyah, G.R. Novelia, B. Husnan, DEMWA, Prosiding Seminar Internasional HATHI$V, 722-732$ (2016)

6. S.S. Fayaed, A. El-Shafie, O. Jaafar, RSSOT, Stoch Environ Res Risk Assess, 27:1751-1772 (2013)

7. M.A. Fulazzaky, CIWRM, Water, 6, 2000-2020 (2014)

8. S.D. Gorantiwar, I.K. Smout, Performance Assessment Of Irrigation Water Management Of Heterogeneous Irrigation Schemes: 1. A Framework
For Evaluation. Irrigation and Drainage Systems, Loughborough University's Institutional Repository (2005)

9. D. Haro, J. Paredes, A. Solera, J. Andreu, MSOWAPWNFP, Water Resour Manage, 26:40594071 (2012)

10. W. Hatmoko, IKAI, Paper Conference, Seminar INAICD, 1 (2014)

11. W. Hatmoko, W. Triweko, D. Yudianto, SPKAA, Jurnal Teknik Hidraulik Puslitbang SDA, 3, 71-86 (2012)

12. G. Irianto, PWS, Kompas (2004)

13. M. Kartabrata, W.D. Marjanto, PCMDAA, Jurnal Informasi Teknik, Ditjen Pengairan-Dep PU, 14, (1994)

14. T.J. Kim, R.A. Wurbs, MRRSM, KSCE Journal of Civil Engineering, 15(8):1457-1467 (2011)

15. Koch, Grunewald, CMSDRWRMP, Water Resour Manage, 23:1403-1422 (2008)

16.Z.W. Kundzewicz, J. Kindler, MCERA, Modelling and Management of Sustainable Basin-scale Water Resource Systems (Proceedings of a Boulder Symposium, July 1995), IAHS Publ. 231, 217 - 224 (1995)

17. K.S. Meijer, W.N.M. Krogt van der, E. Beek van, NAIEFR, Water Resour Manage, 26:1271-1286 (2012)

18. J.K. Mutiga, S.T. Mavengano, S. Zhongbo, T. Woldai, R. Becht, WAPTMWUC, Water Resour Manage, 24:3939-3959 (2010)

19. H. Pawitan, B.I. Setiawan, B. Kartiwa, K. Subagyono, P. Rejekiningrum, MPAPBKL, Laporan Akhir Penelitian Kerja Sama Kemitraan Penelitian Pertanian dengan Perguruan Tinggi (KKP3T) (2009)

20. B.J.C. Perera, B. James, M.D.U. Kularathna, REALM, Journal of Environmental Management, 77, 291-300 (2005)

21. D. Rohmat, UKKKSDA, talk show Hari Air Dunia (2010)

22. R. Roozbahani, B. Abbasi, S. Schreider, A. Ardakani, MATRWA, Water Resour Manage, 28:5447-5463 (2014)

23. R. Roozbahani, B. Abbasi, S. Schreider, OAWCS, Ann Oper Res, 229:657-676 (2015)

24. A. Singh, CMMWR, Hydrogeology Journal, 23: 1217-1227 (2015)

25. H. Sosiawan, K. Subagyono, Strategi Pembagian Air Secara Proporsional Untuk Keberlanjutan Pemanfaatan Air. Balai Besar Penelitian dan Pengembangan Sumberdaya Lahan Pertanian, Pengembangan Inovasi Pertanian 2 (4) (2009)

26. S. Strauß, WC, Hum Ecol, 39:69-79 (2011)

27. S. Suryadi, Kekeringan dan Hak Guna Air, Koran Kompas 09 Agustus (2006)

28. B. Tongongar, C.E. Kan, J.H. Chen, DFT, AmericanEurasian J. Agric. \& Environ. Sci., 3 (3) (2008)

29. UN Water, World Water Development Report 2015, "Water for a Sustainable World", UNESCO (2015)

30. R.A. Wurbs, Comparative Evaluation of Generalized Reservoir/River System Models, Technical Report No. 282 Texas Water Resources Institute (2005) 
31. Y.B. Yazdeli, O.B. Haddad, E.F. Mehdipour, M.A. Mariño, ERSO, Water Resour Manage, 28:715-729 (2014)

32. B. Yulistiyanto, B.A. Kironoto, PPSDA, Media Teknik, 2 (2008)

33. BWS-NT I, Rencana Alokasi Air Tahunan (RAAT) WS Lombok, Balai Wilayah Sungai Nusa Tenggara I (2016) 